Emir. J. Food Agric. 2014. 26 (10): 861-870

doi: 10.9755/ejfa.v26i10.18114

http://www.ejfa.info/

Food Science and Nutrition

REGULAR ARTICLE

\title{
Growth capacity of yeasts potential starter strains under cocoa fermentation stress conditions in Ivory Coast
}

\author{
Lamine Samagaci, Honoré G. Ouattara ${ }^{*}$, Bernadette G. Goualié and Sébastien L. Niamke \\ Laboratoire de Biotechnologies, UFR Biosciences, Université Félix Houphouët-Boigny, Cocody / Abidjan, 22 BP 582 \\ Abidjan 22, Abidjan, Ivory Coast
}

\begin{abstract}
Microbial pectinolytic strains are targeted as potential starter to control cocoa fermentation. This study analyses the ability of yeasts pectinolytic strains to grow under stress conditions. After an initial growth, a decline trend was observed in yeast growth cycle during the cocoa fermentation. The 36 yeasts pectinolytic strains screened from 205 isolates showed tolerance to both alcoholic stress (10-12\% alcohol) and thermic stress (up to $40^{\circ} \mathrm{C}$ ) corresponding to surviving population round $75 \%$. However, temperature-alcohol cross stress provokes full inhibition of strains that failed to grow at only $35^{\circ} \mathrm{C}$ under $8-10 \%$ alcohol. As acid stress, citric acid at $4 \%$ has the same effect as alcohol. In contrast, acetic acid and lactic acid respectively at $0.5 \%$ and $2 \%$ exerted individually, a higher pressure on yeast growth inhibiting up to $60 \%$ the fungal population. However, the viability of yeasts strains to a given concentration of lactic $(1 \%)$ or acetic $(0.25 \%)$ acid proved to be relatively stable with YS201 at increasing temperature up to $40^{\circ} \mathrm{C}$. Cross stress involving temperature and alcohol or single acid stress may be the limiting factor for yeasts pectinolytic growth as starter in controlled cocoa fermentation.
\end{abstract}

Key words: Cocoa fermentation, Stress response, Tolerance, Yeast growth

\section{Introduction}

Cocoa beans before used in chocolate industries need to be fermented and dried. The fermentation which involves two phases of biochemical reactions, is an important and crucial step in the production of commercial cocoa quality (Nielsen, 2005). This process involves mainly yeasts and bacteria including Bacillus, acetic acid bacteria (AAB) and lactic acid bacteria (Ardhana and Fleet, 2003; Schwan and Wheals, 2004; Ouattara et al., 2008; Papalexandratou et al., 2011). During cocoa fermentation, acetic acid bacteria (AAB) oxidize ethanol produced by yeasts, into acetic acid which penetrates into beans and provokes the lowering of the inner $\mathrm{pH}$. Heat produced from exothermic reactions of $\mathrm{AAB}$ and lower $\mathrm{pH}$ triggers the activation of endogenous enzymes, mainly

Received 04 April 2014; Revised 09 July 2014; Accepted 20 July 2014; Published Online 16 September 2014

*Corresponding Author

Honoré G. Ouattara

Laboratoire de Biotechnologies, UFR Biosciences, Université

Félix Houphouët-Boigny, Cocody / Abidjan, 22 BP 582

Abidjan 22, Abidjan, Ivory Coast

Email:kidou12@yahoo.fr proteolytic enzymes (Kirchhoff et al., 1989; Amin et al., 1998), but also aminopeptidase, invertase, polyphenol oxidase and glycosidases. These enzymes provoke the second phase of reaction responsible for final quality of the fermented beans and chocolate.

The first reaction phase to occur during cocoa fermentation comprises external reactions led by the microbial flora using the mucilaginous pulp of the beans as substrate. This phase of reaction leads to the production of acid and alcohol as microbial metabolism products, penetrating into beans and triggering inner reactions. The second phase of reaction occurring deep into the cotyledons, lead to the formation of chocolate specific aroma, but also molecules responsible for the flavor and color characteristics of properly fermented cocoa (Forsyth and Quesnel, 1963, Holm et al., 1993, De Brito et al., 2000, Ouattara et al., 2008).

Moreover, one of the key reactions during this fermentative process is the degradation of the pectin-rich cocoa pulp (Schwan and wheals, 2004, Ouattara et al., 2008).

In fact, the breakdown of the pectin contained in the pulp by pectinolytic enzymes, increase the permeability of the beans. This allows the 
connection between the reactions occurring in the outer part of the bean to those taking place deep inside the beans. Hence, pectin degrading enzymes appear to have a significant impact on cocoa fermented products (Schawn and Wheals, 2004).

As cocoa fermentation is still a traditional process, it is difficult to control variables and production of non-reproducible quality of fermented beans (Schawn and Wheals, 2004), the use of starter culture to ferment the cocoa beans constitute the best approach (Schawn, 1998, Crafack et al., 2013). In this order, it is assumed that a higher production of pectinolytic enzymes is one of the key factors to achieve precise cocoa fermentation control and high crop value for farmers (Schawn, 1998; Schawn and Wheals, 2004, Ouattara et al., 2011). Hence, the screening of pectinolytic strains is an important step in the starter research. Although yeasts are known to be very essential for cocoa fermentation process through their pectinolytic activity (Schawn and Wheals, 2004), many experiments including these types of strains as starter have been conducted without real improvement of cocoa quality (Schawn, 1998, Leal et al., 2008, Crafack et al., 2013). Yet, the use of starter cultures is still absent in current cocoa bean fermentation (Adimpong et al., 2010). In cocoa fermentation, yeasts are subjected to different stress conditions, such as high temperature and high alcohol and acid concentration which may hinder the growth of strains and subsequently impact the pectinolytic enzymes production. Accordingly, a best screening of microbial starter cultures should rely on a deep understanding of their behavior, their characteristic, their functional properties and their stress response to cocoa fermentation condition.

The aim of this study is to evaluate the growth ability and the resistance to environmental stress of yeasts pectinolytic strains involved in Ivory Coast cocoa fermentation.

\section{Material and methods \\ Fermentation conditions}

Cocoa pods were harvested from Agboville (geographic coordinates $5^{\circ} 59^{\prime}$ North $4^{\circ} 28^{\prime}$ West), situated at $79 \mathrm{~km}$ from Abidjan (Côte d'Ivoire). Beans were removed from pods and fermented traditionally by heap fermentation for six days. 100 $\mathrm{kg}$ of cocoa bean constituted of mixed genotypes (Forastero, Trinitario and Criollo cultivars) was fermented by setting the heap on banana leaves and covered with banana leaves. Samples of fermenting cocoa bean were taken according to a fixed time schedule, notably at the start of the fermentation $(0$ h) and after 24, 48, 72, $96 \mathrm{~h}, 120$ and $144 \mathrm{~h}$ of fermentation. $\mathrm{pH}$ and temperature were also regularly recorded directly at $15 \mathrm{~cm}$ depth on the fermenting heap, with portable $\mathrm{pH}$-meter and thermometer (Hanna instruments, Europe, Romania).

\section{Yeasts isolation and enumeration}

After appropriate decimal dilution in sterile saline, the fresh fermented samples were plated on Malt Yeast Peptone Glucose agar containing 3\% yeast extract, 3\% malt extract, 5\% peptone (Himedia), and 1\% glucose, $\mathrm{pH} 5.6$ and $100 \mathrm{mg} / \mathrm{L}$ chloramphenicol (Sigma, Paris, France) to inhibit bacterial growth. The culture was incubated at $30^{\circ} \mathrm{C}$ for $48 \mathrm{~h}$ to enable colony count enumeration (expressed as CFU per gram cocoa pulp-bean mass), as described previously (Lefeber et al., 2012). Yeasts were morphologically identified and the strains isolated were stored at $-80^{\circ} \mathrm{C}$ in MYGP broth supplemented with glycerol $20 \%$ in Eppendorf tubes, for further studies.

\section{Screening of yeasts pectinolytic strains}

The screening was carried out by the method, described by Ouattara et al. (2008). On plate agar containing a basal mineral medium $(0.28 \%$ NH4 SO4, $0.6 \% \quad \mathrm{~K} 2 \mathrm{HPO} 4, \quad 0.01 \% \quad \mathrm{MgSO} 4, \quad 0.2 \%$ $\mathrm{KH} 2 \mathrm{PO} 4$, and $0.5 \%$ glucose) supplemented with $0.02 \%$ yeast extract, $1 \%$ pectin, and $1.7 \%$ Agar with $\mathrm{pH}$ adjusted to 5.6 , five wells of $0.5 \mathrm{~cm}$ in diameter and 2 to $3 \mathrm{~mm}$ in depth were made aseptically in the medium. Then pure yeast culture was suspended in saline tryptone to have an optical density of 1 at $600 \mathrm{~nm}$. The wells were subsequently loaded with $7 \mu \mathrm{l}$ of the suspension. All the wells of the same plate were inoculated with a single suspension. After $48 \mathrm{~h}$ incubation at $30^{\circ} \mathrm{C}$, the solid culture medium was flooded with a solution of iodine and potassium iodide $(5 \mathrm{~g}$ potassium iodide $+1 \mathrm{~g}$ iodine $+330 \mathrm{ml}$ distilled water) to reveal the clear zones around the wells indicating pectinolytic activity (Soares et al., 1999).

\section{Analysis of pectinolytic strains for alcohol and acid tolerance}

The analysis of yeasts to ethanol, lactic acid, acetic acid and citric acid tolerance, was carried out according to the method described by Pereira et al., (2012) with slight modification. The medium was prepared from the basal mineral solution described above and supplemented with $0.05 \%$ yeast extract, $0.3 \%$ vitamin-free Casamino Acids (Difco, Paris, France), $1.7 \%$ agar and the corresponding compound to be analyzed for tolerance. The medium for negative control was prepared in the 
same conditions except that it did not contain the corresponding compound studied. On the other hand, a $24 \mathrm{~h}$ preculture of yeast strains was realized in MYGP broth. Then, cells were pelleted after centrifugation at $4000 \mathrm{rpm}$ and resuspended in saline solution to made an $\mathrm{OD}_{600}=0.2$ and the suspension was then diluted $10^{-5}$ folds in sterile saline solution. A volume of $0.1 \mathrm{ml}$ of this microbial suspension was plated on the medium previously prepared and incubated at $30^{\circ} \mathrm{C}$ for 7 days. Hence, approximately, the same microbial load was used as initial inoculum for all strains. The tolerance of strains was analyzed by enumeration and calculation of the survival rate of yeasts population after incubation using the following formula:

Survival rate $=\left(\sum\right.$ yeast colony with alcohol or acid / $\sum$ yeast colony in negative control) X 100 (Fletcher et al., 1983).

\section{Effects of temperature and $\mathrm{pH}$ on yeasts growth}

The effect of temperature on the growth of yeast strains was investigated by incubating the cultures prepared in the same condition, at different temperatures ranging from 30 to $45^{\circ} \mathrm{C}$ as described by Pereira et al. (2012). The survival growth rate was calculated as mentioned above. To evaluate the effect of $\mathrm{pH}$ on yeasts growth, a $24 \mathrm{~h}$ preculture was realized in MYGP broth. Then, cells were pelleted after centrifugation at $4000 \times \mathrm{g}$, resuspended in MYGP broth and $100 \mu 1$ of the cell suspension was used to inoculate $20 \mathrm{~mL}$ of MYGP broth adjusted to $\mathrm{pH} \mathrm{2,3,4,5}$ and 6 . The absorbance $\left(\mathrm{OD}_{600}\right)$ was measured at $6 \mathrm{~h}$ intervals to monitor the microbial growth during incubation.

\section{Results and discussion \\ Fermentation conditions and yeasts growth}

The temperature of fermenting cocoa mass was $29^{\circ} \mathrm{C}$ at the start of the process and progressively raised to reach a peak at $45^{\circ} \mathrm{C}$ within $48-72 \mathrm{~h}$ (Figure 1A). Then the remaining time, a gradual decrease of temperature was observed, dropping at $36^{\circ} \mathrm{C}$ at the end of fermentation. The same profile of temperature and $\mathrm{pH}$ variation has been regularly recorded in cocoa fermenting mass in many countries (Schwan and Wheals, 2004; Camu et al., 2007; Guehi et al., 2010) indicating that the increase of both parameters constitutes an inherent property of cocoa fermentation worldwide. The initial $\mathrm{pH}$ (3.9) at the beginning of the fermentation, decreased slightly during the 48 first hours (Figure 1B). Then a sharp rise of this $\mathrm{pH}$ was observed reaching 4.4 at $72 \mathrm{~h}$ and 6.07 at $96 \mathrm{~h}$ (Figure 1B). The $\mathrm{pH}$ of cocoa fermenting mass gets its maximum (7.9) at the end of fermentation process. These results are consistent with those found by Guehi et al. (2010) who also reported an alkaline $\mathrm{pH}(8.5)$ at the final stage of cocoa spontaneous fermentation in Côte d'Ivoire. However, it is generally observed that, the $\mathrm{pH}$ of cocoa fermenting bean is maximum at the end of fermentation, but remains acidic (Schwan, 1998; Schwan and Wheals, 2004; Camu et al., 2007). The alkaline pH found in cocoa fermenting bean in Côte d'Ivoire may be a particular trait to this country since alkaline $\mathrm{pH}$ has not been yet reported in other country.
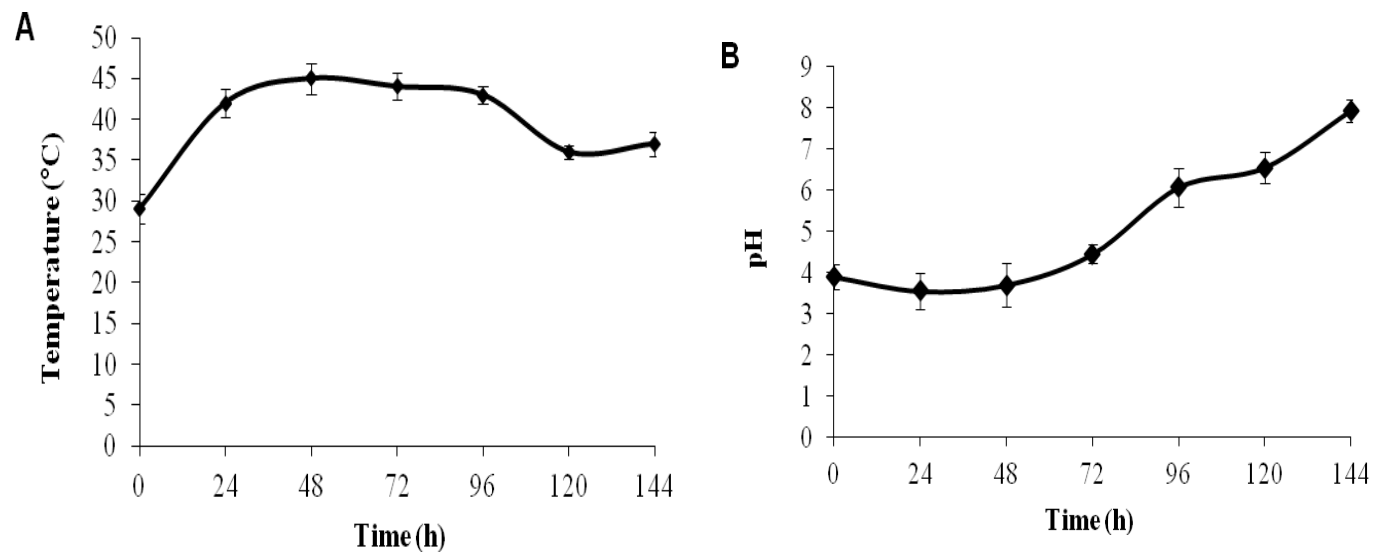

Figure 1. Evolution of temperature and $\mathrm{pH}$ during cocoa fermentation. (A) $\mathrm{pH}$, (B) Temperature. Error bars indicate standard deviation between three replicates. (This figure has been reproduced from Yao et al., 2014). 
Enumeration of yeast population during the cocoa fermentation shows that the load of yeasts was already $3.67 \mathrm{log}$ (CFU/g of bean) at the beginning of the process (Figure 2). Then the following hours, a strong increase of yeasts population was observed, reaching maximum load at $4.24 \mathrm{log}$ (CFU/g of bean) after $24 \mathrm{~h}$. Hence, no lag phase for yeasts growth was observed during this fermentative process. This is probably due to suitable growth conditions for yeasts prevailing in the initial phase of cocoa fermentation. Generally, cocoa fermentation begins under anaerobic, low $\mathrm{pH}$ and temperature conditions with high sugar content in the pulp; which constitute all together, a unique favorable environment for yeasts growth (Schwan and Wheals, 2004). Favorable conditions for yeast growth seem to have prevailed until $48 \mathrm{~h}$, of fermentation, since the load of yeast in the fermenting mass increased and remained approximately maximum in this period (Figure 2). Over $48 \mathrm{~h}$ of fermentation, a regular and drastic decrease of yeasts population occured and yeast population dropped at $2.69 \log (\mathrm{CFU} / \mathrm{g}$ of bean) at the end of the process. The drop of yeasts load during this period might be due to the relatively high temperature $\left(42-45^{\circ} \mathrm{C}\right)$ observed in the fermenting mass after $48 \mathrm{~h}$ (Figure 1A), but also due to eventual accumulation of alcohol and acids produced. The decrease of yeasts population after $48 \mathrm{~h}$ of fermentation also indicates that cocoa fermentation undoubtedly implies some stress conditions susceptible to limit microbial growth and subsequently to counterbalance their potential desired technological properties.

From these results, two distinguished period of yeasts growth can be drawn: a favourable growth period spanning from the start to $48 \mathrm{~h}$, and a stress period beyond $48 \mathrm{~h}$ of fermentation corresponding to occurrence of limiting factor for the growth of yeasts cells. The same pattern of yeasts growth during cocoa fermentation was observed in Ghana, Brazil, and Indonesia (Sanchez et al., 1985; Jespersen et al., 2005; Nielsen et al., 2005; Pereira et al., 2012).

Samples of fermenting bean were harvested at $24 \mathrm{~h}$ interval, and microbial numeration was performed by decimal dilution method on MYGP agar supplemented with $100 \mathrm{mg} / \mathrm{L}$ of chloramphenicol and plate was incubated at $30^{\circ} \mathrm{C}$ for $48 \mathrm{~h}$ (Lefeber et al., 2012). Error bars indicate standard deviations between three replicates.

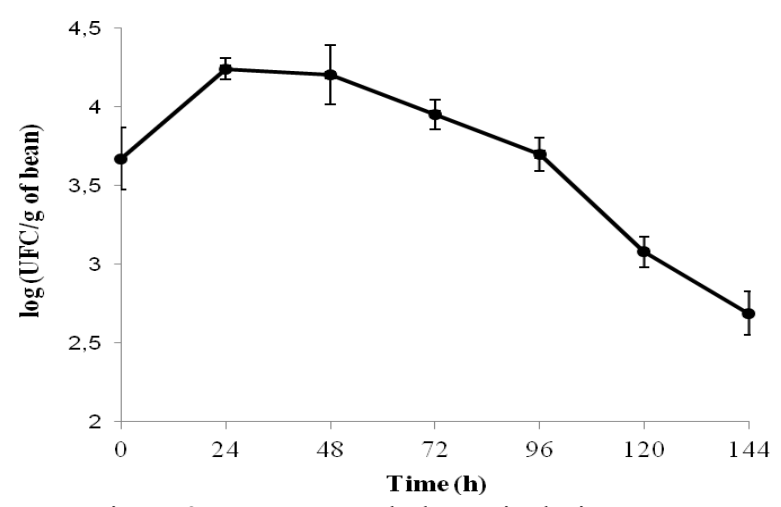

Figure 2. Yeasts growth dynamic during cocoa fermentation.

\section{Screening of pectinolytic strains}

Two hundred and five (205) yeast strains were isolated from cocoa fermenting beans and screened for pectinolytic activity. Of them, 36 were able to produce pectinolytic enzymes as revealed by clear zone round the colonies with halo diameter comprised between 0.7 and $3 \mathrm{~cm}$. The proportion of yeasts pectinolytic isolated from Ivory Coast cocoa fermentation is relatively low with percentage of $17.56 \%$. As pectinolytic strains are very important for cocoa fermentation process (Schwan and Wheals, 2004; Leal et al., 2008), expression of this technological property, is naturally related to strains survival capacity under fermentation conditions. Hence, the best pectinolytic yeasts isolated based on halo diameter were further studied for their response to stress conditions such as high temperature, high alcohol and acid concentration and low $\mathrm{pH}$ which are known to occur during cocoa fermentation.

\section{Effect of temperature and $\mathrm{pH}$ on pectinolytic yeasts growth}

The Figure 3 shows that pectinolytic strains present a very good growth at $40^{\circ} \mathrm{C}$ with survival rate more than $100 \%$. However, at $45^{\circ} \mathrm{C}$ no growth was observed. Therefore, it could be thought that our pectinolytic yeasts strains may not be fully viable at temperature beyond $40^{\circ} \mathrm{C}$ in fermentation condition. Meanwhile, numerous yeasts strains have been isolated after $24 \mathrm{~h}$ of fermentation, corresponding to the period at which fermenting mass was about $45^{\circ} \mathrm{C}$ (Figure 1A). This suggests that yeasts strains should be capable of adaptive response in natural conditions of cocoa fermentation.

Strains were grown on MYGP agar plate at different temperature during 7 days. After incubation, microbial numeration was performed and the survival rate (\%) was calculated with 
negative control. Error bars indicate standard deviations between three replicates.

On the other hand, the Table 1 indicates, in vitro, strains were able to grow at low $\mathrm{pH}(\mathrm{pH} 2)$ but with a very low growth rate. The optimum $\mathrm{pH}$ for yeast growth isolated was $\mathrm{pH} 5$.

\section{Alcohol tolerance of pectinolytic strains}

All the 36 pectinolytic strains were analysed for alcohol tolerance. The results show that nearly half of them are able to grow at $30^{\circ} \mathrm{C}$ on medium containing up to $10 \%$ alcohol, and only 7 strains supported $12 \%$ of alcohol concentration (data not show). Four strains presenting the strongest pectinolytic capacity and supporting up to $10-12 \%$ of ethanol concentration have been screened for further studies. The Figure 4 shows that the tolerance of yeasts strains to alcohol at 10 and $12 \%$ concentration concerned $60-75 \%$ of microbial cell which remained viable at these alcohol concentrations. The drastic death of yeasts population beyond $10-12 \%$ alcohol (Figure 4), gives an insight into the pressure exerted by alcoholic stress on yeasts strains. In fact, ethanol is an inhibitor of yeast growth; even at relatively low concentrations, it inhibits cell division, decreases cell volume and specific growth rate, while high ethanol concentrations reduce cell vitality and increase cell death (Birch and Walker, 2000). The maximum yield of ethanol in cocoa mass was found to be round $0.8 \%(\mathrm{w} / \mathrm{v})$ (Schwan, 1998) and 8\% $(\mathrm{w} / \mathrm{w})$ (Pereira et al., 2012). In this order, the tolerance up to $12 \%$ ethanol presented by certain yeast pectinolytic strains isolated in this work appears to be very interesting since, this indicates that these strains are amply capable to survive under alcoholic stress conditions during cocoa fermentation. Pereira et al. (2012) have also isolated from Mexico fermenting cocoa bean, some non pectinolytic yeasts strains which tolerate ethanol between 6 and $12 \%$ concentration.

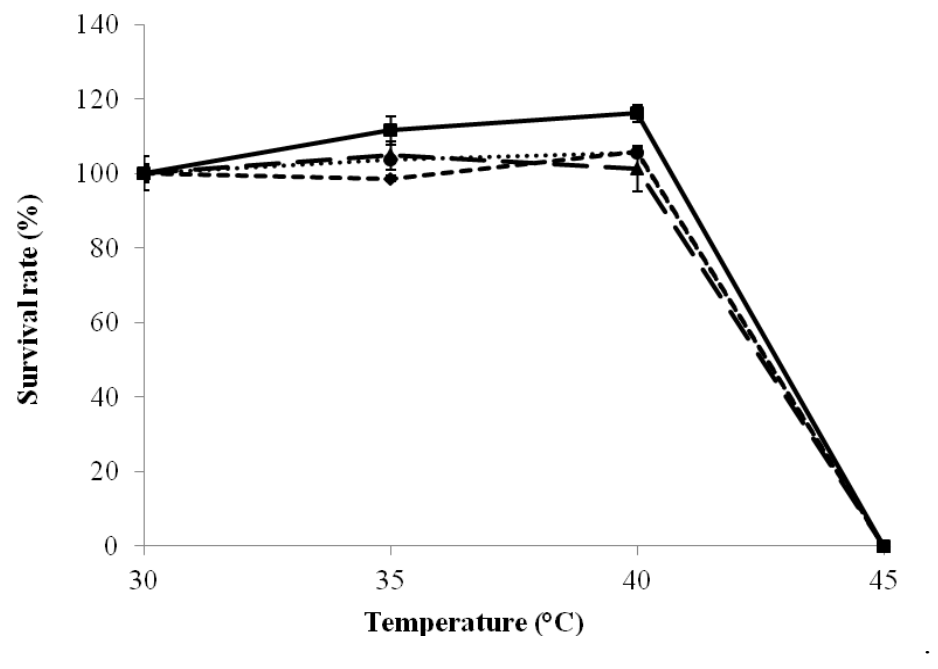

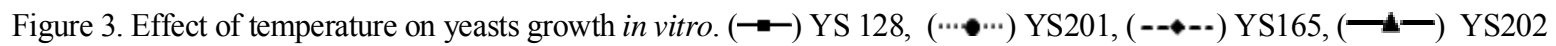

Table 1. Effect of $\mathrm{pH}$ on pectinolytic yeasts strains.

\begin{tabular}{|c|c|c|c|c|c|}
\hline \multirow{2}{*}{ Yeasts Strains } & \multicolumn{5}{|c|}{ Absorbance $(600 \mathrm{~nm})$} \\
\hline & $\mathrm{pH} 2.0$ & $\mathrm{pH} 3.0$ & $\mathrm{pH} 4.0$ & pH 5.0 & pH 6.0 \\
\hline YS 128 & $1.09( \pm 0.01)$ & $1.33( \pm 0.02)$ & $1.37( \pm 0.08)$ & $1.37( \pm 0.05)$ & $1.41 \pm 0.01)$ \\
\hline YS 201 & $1.06( \pm 0.05)$ & $1.20( \pm 0.04)$ & $1.25( \pm 0.04)$ & $1.43( \pm 0.87)$ & $1.38( \pm 0.07)$ \\
\hline YS 165 & $0.96( \pm 0.03)$ & $1.35( \pm 0.01)$ & $1.35( \pm 0.02)$ & $1.41( \pm 0.00)$ & $1.36( \pm 0.00)$ \\
\hline YS 202 & $0.99( \pm 0.06)$ & $1.27( \pm 0.03)$ & $1.24( \pm 0.03)$ & $1.29( \pm 0.02)$ & $1.23( \pm 0.02)$ \\
\hline
\end{tabular}

Strains were grown in MYGP broth at different $\mathrm{pH}$. The growth was monitored at $6 \mathrm{~h}$ interval and the absorbances corresponding to the end of exponential growth phase are indicated. 


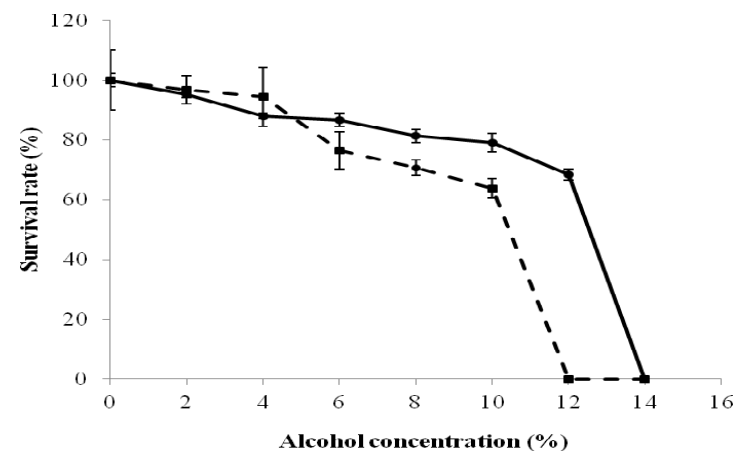

Figure 4. Effect of alcohol on yeast growth in vitro. $(\longrightarrow)$ YS 201, ( • -) YS 128.

Strains were grown on basal medium plate supplemented with corresponding alcohol and citric acid volume and the plate was incubated at $30^{\circ} \mathrm{C}$ during 7 days. After incubation, microbial numeration was performed and the survival rate (\%) was calculated with negative control. Error bars indicate standard deviations between three replicates.

However, we further checked whether the alcohol tolerance observed at $30^{\circ} \mathrm{C}$ with certain yeasts pectinolytic strains, is stable at higher temperatures using the strains YS128, YS201, YS165 and YS202 as model. The Table 2 shows that strains presenting a capacity to grow in a medium containing $10-12 \%$ alcohol at $30^{\circ} \mathrm{C}$, with survival rate round $75 \%$, failed to grow on the same medium at $35^{\circ} \mathrm{C}$. This clearly indicates that the alcohol tolerance of pectinolytic yeasts strains is not stable with the temperature. The loss of ethanol tolerance at temperature higher than $30^{\circ} \mathrm{C}$ observed in yeasts strains studied in the present work, suggest that cells are not able to develop a response to crossed stress such as alcoholic and heat stress. The response of yeast to environmental stress is complex, involving various aspects of cell sensing, signal transduction, transcriptional and posttranscriptional control, protein-targeting, accumulation of protectants, and increased activity of repair functions (Mager and Ferreira, 1993). The efficiency of these biological mechanisms in a given yeast strain determines its robustness and, to a large extent, ability of a given strain to perform well in technological processes (Stanley et al., 2010).

\section{Acid tolerance of pectinolytic strains Citric acid}

Citric acid is a compound responsible for the initial low $\mathrm{pH}$ of the cocoa pulp. The Figure 5 shows that yeasts strains are able to grow under acidity conditions up to $4 \%$ of citric acid at $30^{\circ} \mathrm{C}$. At this concentration the results indicate a survival rate superior to $60 \%$. Furthermore, the strain YS201 was able to keep the same viability at $5 \%$ citric acid. The studies aiming to evaluate the effect of citric acid on yeast growth such as the present work are inexistent at date. More studies are focused on molecular basis of citric acid tolerance in food spoilage yeasts (Piper et al., 2001; Stratford et al., 2013). However, citric acid at approximately $1.2 \%$ was found to inhibit significantly the growth of Escherichia coli O157:H7 (Bjornsdottir et al., 2006). To this point of view, it could be assumed that yeasts isolated retaining more than $60 \%$ of viable cells at $5 \%$ citric acid present a relative high tolerance to this acid.

Strains were grown on basal medium plate supplemented with corresponding acetic acid volume and the plate was incubated at $30^{\circ} \mathrm{C}$ during 7 days. After incubation, microbial numeration was performed and the survival rate (\%) was calculated with negative control. Error bars indicate standard deviations between three replicates.

Moreover, yeasts strains also lost this tolerance at temperature beyond $30^{\circ} \mathrm{C}$, like alcohol tolerance (Table 3).

Table 2. Growth capacity of yeasts strains under alcoholic stress at various temperatures.

\begin{tabular}{|c|c|c|c|c|c|c|}
\hline \multirow{3}{*}{$\begin{array}{l}\text { Yeasts } \\
\text { Strains }\end{array}$} & \multicolumn{6}{|c|}{ Survival rate $(\%)$} \\
\hline & \multicolumn{2}{|l|}{$30^{\circ} \mathrm{C}$} & \multicolumn{2}{|l|}{$35^{\circ} \mathrm{C}$} & \multicolumn{2}{|l|}{$40^{\circ} \mathrm{C}$} \\
\hline & $\begin{array}{l}\text { Without } \\
\text { alcohol }\end{array}$ & $\begin{array}{l}\text { With } \\
\text { alcohol }\end{array}$ & $\begin{array}{l}\text { Without } \\
\text { alcohol }\end{array}$ & $\begin{array}{l}\text { With } \\
\text { alcohol }\end{array}$ & $\begin{array}{l}\text { Without } \\
\text { alcohol }\end{array}$ & $\begin{array}{l}\text { With } \\
\text { alcohol }\end{array}$ \\
\hline YS 128 & $100( \pm 6.14)$ & $72.42( \pm 4.83)$ & $107.53( \pm 3.83)$ & 0 & $113.15( \pm 2.31)$ & 0 \\
\hline YS 201 & $100( \pm 12.15)$ & $79.54( \pm 2.52)$ & $103.21( \pm 0.37)$ & 0 & $104.61( \pm 0.74)$ & 0 \\
\hline YS165 & $100( \pm 11.06)$ & $76.66( \pm 2.27)$ & $98( \pm 0.88)$ & 0 & $102.77( \pm 0.88)$ & 0 \\
\hline YS 202 & $100( \pm 14.59)$ & $76.19( \pm 2.38)$ & $104( \pm 0.87)$ & 0 & $98.31( \pm 3.05)$ & 0 \\
\hline
\end{tabular}

Alcohol was used at $8 \%$ for strains YS 128, YS 202 and $10 \%$ for the strains YS 165, YS 201. 
Table 3. Growth capacity of yeasts strains under citric acid stress at various temperatures.

\begin{tabular}{|c|c|c|c|c|c|c|}
\hline \multirow{3}{*}{$\begin{array}{l}\text { Yeasts } \\
\text { Strains }\end{array}$} & \multicolumn{6}{|c|}{ Survival rate $(\%)$} \\
\hline & \multicolumn{2}{|l|}{$30^{\circ} \mathrm{C}$} & \multicolumn{2}{|l|}{$35^{\circ} \mathrm{C}$} & \multicolumn{2}{|l|}{$40^{\circ} \mathrm{C}$} \\
\hline & $\begin{array}{l}\text { Without citric } \\
\text { acid }\end{array}$ & $\begin{array}{l}\text { With } \\
\text { citric acid }\end{array}$ & $\begin{array}{l}\text { Without } \\
\text { citric acid }\end{array}$ & $\begin{array}{l}\text { With } \\
\text { citric acid }\end{array}$ & $\begin{array}{l}\text { Without } \\
\text { citric acid }\end{array}$ & $\begin{array}{l}\text { With } \\
\text { citric acid }\end{array}$ \\
\hline YS 128 & $100( \pm 9.18)$ & $30.98( \pm 4.69)$ & $102.53( \pm 7.63)$ & 0 & $106.15( \pm 3.11)$ & 0 \\
\hline YS 201 & $100( \pm 10.87)$ & $62.64( \pm 2.05)$ & $93.21( \pm 7.37)$ & 0 & $89.61( \pm 4.74)$ & 0 \\
\hline YS165 & $100( \pm 8.46)$ & $53.26( \pm 2,12)$ & $94.33( \pm 6.18)$ & 0 & $98.79( \pm 6.88)$ & 0 \\
\hline YS 202 & $100( \pm 13.79)$ & $64.81( \pm 1.72)$ & $99.00( \pm 4.82)$ & 0 & $96.11( \pm 2.01)$ & 0 \\
\hline
\end{tabular}

Citric acid was used at $5 \%$ for strains YS 128, YS 201 and $6 \%$ for strains YS 202, YS 165.

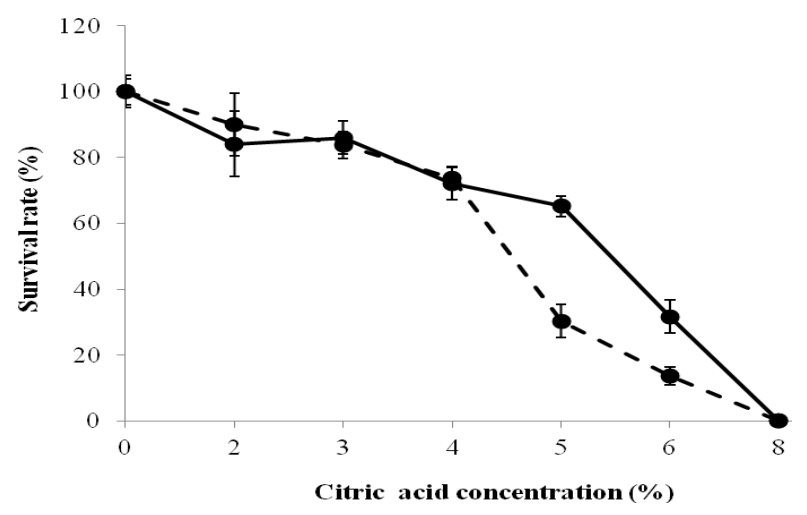

Figure 5. Effet of acetic acid on yeast growth in vitro.

$(\bullet-)$ YS201, (-• -) YS128.

\section{Acetic and lactic acid}

The Figure 6 indicates that at $30^{\circ} \mathrm{C}$, acetic acid at $0.25 \%$ in the basal medium seems to promote the growth of yeast strain YS128. While, the same concentration of acetic acid gives a good growth of yeast strain YS201 with about $80 \%$ of survival rate. In addition, both strains still have a middle tolerance to acetic acid at $0.5 \%$ with a survival rate round $40 \%$. However, at $0.75 \%$, acetic acid entirely suppresses the growth of all yeast strain (Figure 6). Acetic acid at $0.6 \%(\mathrm{w} / \mathrm{v})$ was found to exert full inhibition on the growth rate of Saccharomyces cerevisea (Narendranath et al., 2001). Likewise, several yeasts strains belonging to the genus Candida failed to grow under acetic acid at concentrations ranging between 0.2 and $0.8 \%(\mathrm{w} / \mathrm{v})$ (Lazarova et al., 1990). It is reported that the maximum yield of acetic acid was around $0.6 \%$ in cocoa mass after $72 \mathrm{~h}$ of fermentation (Schwan, 1998). In these conditions, only a week population, approximately $20 \%$ of yeasts strains should remain viable (Figure 6), and their fermentative performance, notably their ability to produce pectinolytic enzymes is liable to be strongly impaired. Hence, a production of acetic acid beyond $0.6 \%$ by bacteria during cocoa fermentation may be one of the main factors influencing yeasts stress. However, the yield of acetic acid during fermentation depending on numerous factors is variable; Pereira et al. (2012) measured approximately $0.7 \%$ as total organic acid content in the pulp after $72 \mathrm{~h}$ of fermentation.

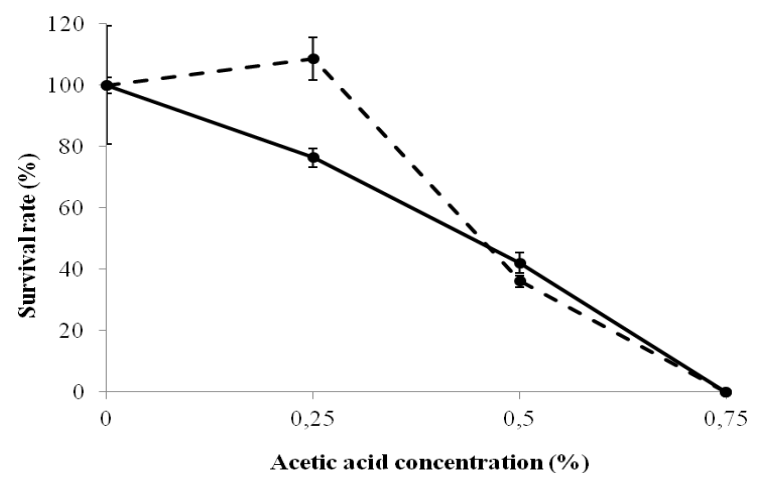

Figure 6. Effet of acetic acid on yeast growth in vitro.

$$
(\multimap) \text { YS201, (-• -) YS128. }
$$

Strains were grown on basal medium plate supplemented with corresponding lactic acid volume and the plate was incubated at $30^{\circ} \mathrm{C}$ during 7 days. After incubation, microbial numeration was performed and the survival rate (\%) was calculated with negative control. Error bars indicate standard deviations between three replicate.

Very interestingly, the relative tolerance of yeasts strains to acetic acid at $0.25 \%$ shows a strong stability, when the temperature increases up to $40 \%$ (Table 4).

Another organic acid, notably lactic acid studied in this work was found to inhibit fully the growth of yeasts strains at 3\% concentration (Figure 7). The strains YS128 kept more than 25\% of viable cell at $2 \%$ of lactic acid, while more than $50 \%$ of cell remained viable with the strain YS201 (Figure 7). 
Table 4. Growth capacity of yeasts strains under acetic acid stress at various temperatures.

\begin{tabular}{|c|c|c|c|c|c|c|}
\hline \multirow{3}{*}{$\begin{array}{l}\text { Yeasts } \\
\text { strains }\end{array}$} & \multicolumn{6}{|c|}{ Survival rate $(\%)$} \\
\hline & \multicolumn{2}{|l|}{$30^{\circ} \mathrm{C}$} & \multicolumn{2}{|l|}{$35^{\circ} \mathrm{C}$} & \multicolumn{2}{|l|}{$40^{\circ} \mathrm{C}$} \\
\hline & $\begin{array}{l}\text { Without } \\
\text { acetic acid }\end{array}$ & $\begin{array}{l}\text { With } \\
\text { acetic acid }\end{array}$ & $\begin{array}{l}\text { Without } \\
\text { acetic acid }\end{array}$ & $\begin{array}{l}\text { With } \\
\text { acetic acid }\end{array}$ & $\begin{array}{l}\text { Without } \\
\text { acetic acid }\end{array}$ & $\begin{array}{l}\text { With } \\
\text { acetic acid }\end{array}$ \\
\hline YS128 & $100( \pm 13.61)$ & $111.73( \pm 2.23)$ & $99.53( \pm 6.85)$ & $91.06( \pm 8.37)$ & $98.15( \pm 5.22)$ & $92.73( \pm 5.64)$ \\
\hline YS201 & $100( \pm 07.18)$ & $93.39( \pm 17.62)$ & $95.21( \pm 9.37)$ & $82.37( \pm 1.32)$ & $96.61( \pm 3.48)$ & $72.24( \pm 17.62)$ \\
\hline YS165 & $100( \pm 12.27)$ & $142.82( \pm 27.3)$ & $100( \pm 7.88)$ & $96.42( \pm 7.14)$ & $102.13( \pm 9.38)$ & $92.26( \pm 0.59)$ \\
\hline YS202 & $100( \pm 2.70)$ & $102.7( \pm 13.51)$ & $95.17( \pm 5.91)$ & $57.09( \pm 1.01)$ & $90.22( \pm 3.13)$ & $52.7( \pm 1.35)$ \\
\hline
\end{tabular}

Acetic acid was used at $0.25 \%$ in the basal medium plate.

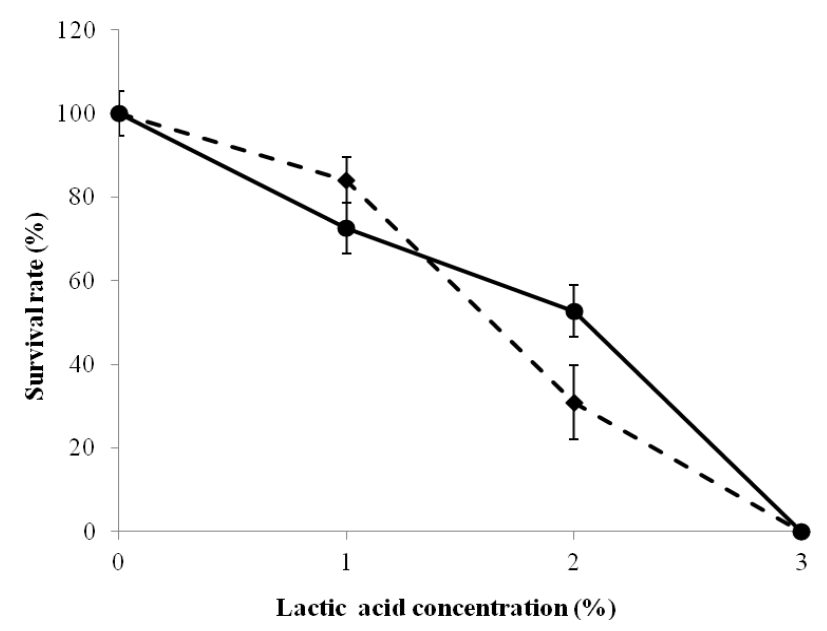

Figure 7. Effet of lactic acid on yeast growth in vitro. ( $\bullet$ ) YS201, ( - • -) YS128.

Strains were grown on basal medium plate supplemented with corresponding lactic acid volume and the plate was incubated at $30^{\circ} \mathrm{C}$ during 7 days. After incubation, microbial numeration was performed and the survival rate (\%) was calculated with negative control. Error bars indicate standard deviations between three replicate.

Moreover, the relative acid tolerance in the strain YS201 proved to be thermic stable with more than $75 \%$ of viable cell observed at up to $40^{\circ} \mathrm{C}$, while the other strains shows poor growth at $35^{\circ} \mathrm{C}$ and $40^{\circ} \mathrm{C}$ even at $1 \%$ of lactic acid concentration (Table 5). Lactic acid bacteria constitute one of the main microflora which are able to produce up to 2$3 \%$ of lactic acid during cocoa fermentation (Schwan, 1998; Pereira et al., 2012). Since, this study shows that lactic acid at $2-3 \%$ inhibit strongly the growth of pectinolytic yeasts strain (Figure 7), it is believable that this acid could be together with acetic acid the main factors of yeast growth inhibition during the stress period of fermentation.

Table 5. Growth capacity of yeasts strains under lactic acid stress at various temperatures.

\begin{tabular}{|c|c|c|c|c|c|c|}
\hline \multirow{3}{*}{$\begin{array}{l}\text { Yeasts } \\
\text { Strains }\end{array}$} & \multicolumn{6}{|c|}{ Survival rate (\%) } \\
\hline & \multicolumn{2}{|l|}{$30^{\circ} \mathrm{C}$} & \multicolumn{2}{|l|}{$35^{\circ} \mathrm{C}$} & \multicolumn{2}{|l|}{$40^{\circ} \mathrm{C}$} \\
\hline & $\begin{array}{l}\text { Without } \\
\text { lactic acid }\end{array}$ & $\begin{array}{l}\text { With } \\
\text { Lactic acid }\end{array}$ & $\begin{array}{l}\text { Without } \\
\text { lactic acid }\end{array}$ & $\begin{array}{l}\text { With } \\
\text { lactic acid }\end{array}$ & $\begin{array}{l}\text { Without } \\
\text { lactic acid }\end{array}$ & $\begin{array}{l}\text { With } \\
\text { lactic acid }\end{array}$ \\
\hline YS 128 & $100( \pm 11.21)$ & $83.49( \pm 2.23)$ & $104.53( \pm 3.43)$ & $19.16( \pm 8.37)$ & $108.15( \pm 3.51)$ & $10.35( \pm 15.64)$ \\
\hline YS 201 & $100( \pm 16.83)$ & $73.6( \pm 17.62)$ & $101.21( \pm 1.31)$ & $74.80( \pm 1.32)$ & $97.61( \pm 3.77)$ & $75.2( \pm 17.62)$ \\
\hline YS165 & $100( \pm 16.66)$ & $86.0( \pm 27.38)$ & $96.00( \pm 11.03)$ & $46.93( \pm 7.14)$ & $94.77( \pm 5.63)$ & $16.32( \pm 0.59)$ \\
\hline YS 202 & $100( \pm 9.43)$ & $87.83( \pm 13.51)$ & $97.00( \pm 1.73)$ & $49.22( \pm 1.01)$ & $99.34( \pm 3.50)$ & $15.25( \pm 1.35)$ \\
\hline
\end{tabular}

Lactic acid was used at $1 \%$ in the basal medium. 


\section{Conclusions}

It appeared that pectinolytic yeast strains showed a very good tolerance to ethanol and is believed to response well to alcoholic stress during fermentation. However, they were not able to survive to alcohol and temperature cross stress. Likewise, yeasts strains, were not able to develop a response to combined acid and heat shocks, except the strain YS201 which was found to be able to grow under temperature-acid cross stress. So, the strain YS201 revealed to be a valuable starter strain for cocoa fermentation. This study indicates that, a combination of temperature with other factor such as alcohol or acid, constitute the main stress hindering the growth of pectinolytic yeasts strains in cocoa fermentation. Perhaps, the strategy for finding the best starter should not be to screen pectinolytic strains resistant to environmental stress but to search for pectinolytic strains capable to perform their maximum potential within the shortest time before entering in the stress period of fermentation.

\section{Acknowlegment}

This research was supported by the International Foundation for Science, Sweden, under grant $\mathrm{E} / 4411-2$.

\section{References}

Adimpong, B. D., D. S. Nielsen, K. I. Sorensen, P. M. F. Derkx and L. Jespersen. 2010. Genotypic and technological characterization of lactic acid bacteria from indigenous fermented African foods. In: Functional food and sustainable food production 'food Denmark PhD congress 2010'. Copenhagen, Denmark, p.28.

Amin, I., S. Jinap and B. Jamilah. 1998. Proteolytic activity (aspartic endoproteinase and carboxypeptidase) of cocoa bean during fermentation. J. Sci. Food Agric. 76:123-128.

Ardhana, M. and G. Fleet. 2003. The microbial ecology of cocoa bean fermentations in Indonesia. Int. J. Food Microbiol. 86:87-99.

Birch, R. M. and G. M. Walker. 2000. Influence of magnesium ions on heat shock and ethanol stress responses of saccharomyces cerevisiae. Enzyme Microb. Technol. 26:678-687.

Bjornsdottir, K., F. Jr- Breidt and R. F. Feeters. 2006. Protective effects of organic acids on survival of Escherichia coli O157: H7 in acidic environments. Appl. Environ. Microbiol. 72:660-664.
Camu, N., T. De Winter, K. Verbruggle, I. Cleenwerck, P. Vandamme, J. S. Takrama, M. Vancanneyt and L. De Vuyst. 2007. Dynamics and biodiversity of populations of lactic acid bacteria and acetic acid bacteria involved in spontaneous heap fermentation of cocoa beans in Ghana. Appl. Environ. Microbiol. 73:18091824.

Crafack, M., M. Mikkelsen, S. Saerens, M. Kundsen, A. Blenbow, S. Lowor, J. Takrama, J. Swiegers, G. B. Petersen, H. Heimdal and D. S. Nielsen. 2013. Influencing cocoa flavor using Pichia klutveri and Kluyveromyces marxianus in a defined starter culture for cocoa fermentation. Int. J. Food Microbiol. 167:103-116.

De Brito, E. S., G. N. H. Pezoa, M. I. Gallão, A. L. Cortelazzo, P. S. Fevereiro and M. R. Braga. 2000. Structural and chemical changes in cocoa (Theobroma cocoa L.) during fermentation drying and roasting. J. Sci. Food Agric. 81:281-288.

Fletcher, R. D., A. C. Albers, A. K. Chen and J. N. Albertson Jr. 1983. Ascorbic acid inhibition of Campylobacter jejuni growth. Appl. Environ. Microbiol. 45:792-795.

Forsyth, W. G. C. and V. C. Quesnel. 1963. Mechanisms of cocoa curing. Adv. Enzymol. 25:457-492.

Guehi, S. T., S. Dabone, L. Ban-Koffi, D. K. Kra and G.I. Zahouli. 2010. Effect of turning beans and fermentation method on the acidity and physical quality of raw cocoa beans. Adv. J. Food Sci. Technol. 2:163-171.

Holm, C. S., J. W. Aston and K. Douglas. 1993. The effects of the organic acids in cocoa on flavour of chocolate. J. Sci. Food Agric. 61:65-71.

Jespersen, L., D. S. Nielsen, S. Honholt and M. Jakobsen. 2005. Occurrence and diversity of yeasts involved in fermentation of West African beans. FEMS Yeast Res. 5:441-453.

Kirchhoff, P. M., B. Biehl, H. ZiegelerBerghausen, M. Hammoor and R. Lieberei. 1989. Kinetics of the formation of free amino acids in cocoa seeds during fermentation. Food Chem. 34:161-179.

Lazarova, G., V. Kostov, S. Zhelev, V. Ivanova and T. Sokoloov. 1990. The effect of acetic acid 
and furfural on yeast growth. Acta Microbiol. Bulg. 25:24-30.

Leal, G. A., L. H. Gomes, P. Efraim, F. C. A. Tavares and A. Figueira. 2008. Fermentation of cacao (Theobroma cacao L.) seeds with a hybrid Kluyveromyces marxianus strain improved product quality attributes. FEMS Yeast Res. 8:788-798.

Lefeber, T., Z. Papalexandratou, W. Gobert, N. Camu and L. De Vuyst. 2012. On-farm implementation of starter culture for improved cocoa bean fermentation and its influence on the flavor of chocolate produced thereof. Food Microbiol. 30:379-392.

Mager, W. H. and P. M. Ferreira. 1993. Stress response of yeast. Biochem. J. 290:1-13.

Narendranath, N. V., K. C. Thomas and W. N. Ingledew. 2001. Effects of acetic acid and lactic acid on the growth of Saccharomyces cerevisiae in a minimal medium. J. Indus. Microbiol. Biotechnol. 26:171-177.

Nielsen, D. S., S. HØnholt, T. Debrah and L. Jespersen. 2005. Yeasts populations associated with Ghanaian cocoa fermentations analyzed using denaturing gradient gel electrophoresis (DGGE). Yeast 22:271-284.

Ouattara, H. G., L. Ban-Koffi, G. T. Karou, A. Sangare, S. L. Niamke and J. K. Diopoh. 2008. Implication of Bacillus sp. in the production of pectinolytic enzymes during cocoa fermentation. World J. Microbiol. Biotechnol. 24:1753-1760.

Ouattara, H. G., S. Reverchon, S. L. Niamke and W. Nasser. 2011. Molecular identification and pectate lyase production by Bacillus strains involved in cocoa fermentation. Food Microbiol. 28:1-8.

Papalexandratou, Z., G. Vranckena, K. De Bruyne, P. Vandamme and L. De Vuyst. 2011. Spontaneous organic cocoa bean box fermentations in Brazil are characterized by a restricted species diversity of lactic acid bacteria and acetic acid bacteria. Food Microbiol. 28:1326-1338.
Pereira, G. V. M., M. G. C. P. Migue, C. L. Ramos, R. F. Schwan. 2012. Microbiological and Physicochemical characterization of smallscale cocoa fermentations and screening of yeast and bacterial strains to develop a defined starter culture. Appl. Env. Microbiol. 78:53955405 .

Piper, P., C. O. Calderon, K. Hatzixanthis and M. Mollapour. 2001. Weak acid adaptation: the stress response that confers yeasts with resistance to organic acid food preservatives. Microbiol. 147:2635-2642.

Sanchez, J., G. Daguenet, J. P. Guiraud, J. C. Vincent and P. Galzy. 1985. A study of the yeast flora and the effect of pure culture seeding during the fermentation of cocoa beans. Lebensm. wiss. Technol. 18:69-76.

Schwan, R. F. 1998. Cocoa fermentation conducted with a defined microbial cocktail inoculum. Appl. Env. Microbiol. 64:1477-1483.

Schwan, R. F. and A. E. wheals. 2004. The microbiology of cocoa fermentation and its role in chocolate quality. Crit. Rev. Food Sci. Nutr. 44:204-221.

Soares, M. M. C. N., R. Da Silva and E. Gomes. 1999. Screening of bacterial strain for pectinolytic activity: characterization of the polygalacturonase produced by Bacillus sp. Revista Microbiol. 30:229-303.

Stanley, D., A. Bandara, S. Fraser, P. J. Chambers and G. A. Stanley. 2010. The ethanol stress response and ethanol tolerance of Saccharomyces cerevisiae. J. Appl. Microbiol. 109:13-24.

Stratford, M., H. Steels, G. Nebe-Von-Caron, M. Novodrorska, K. Hayer and D. B. Archer. 2013. Extreme resistance to weak-acid preservatives in the spoilage yeast Zygosaccharomyces bailii. Int. J. Food Microbiol. 166:126-134.

Yao, W., H. G. Ouattara, B. Goualie, S. Soumahoro and S. Niamke. 2014. Analysis of some functional properties of acetic acid bacteria involved in Ivorian cocoa fermentation. J. Appl. Biosci. 75:6282-6290. 